\title{
Carotid endarterectomy versus stenting in octogenarians
}

\author{
A Savanelli, R Compagna, D De Vito, R Rossi, F Fappiano, T Bianco, M Amato, B Amato \\ From XXIII Annual Meeting of the Italian Society of Geriatric Surgery \\ Lecce, Italy. 2-4 December 2010
}

\section{Background}

Stents are an alternative treatment to carotid endarterectomy (CEA) for symptomatic carotid stenosis, but previous trials have not established equivalent safety and efficacy in octuogenarian patients. We compared the safety of carotid stenting carotid endarterectomy (CAS). We conducted retrospective review of all cases of carotid stenosis treated with CEA and CAS.

\section{Materials and methods}

During a 7 year period from October 2000 to April 2007, 84 symptomatic carotid stenosis were treated at Department of general surgery of AUO "Federico II" of Naples 48 with CAS and 36 with CEA. We divided our patients in two group not randomly but according to valuation anesthesia. The age range in this group was 80 to 89 years (average age of 82.7 years). The indication for treatment were transient ischemic attack in (43.1\%). Cerebrovascular accident in (23\%), amaurosis fugax in (9.3\%), vascular tinnitus in (2.6\%) Associated risk factors included systemic arterial hypertension, diabetes mellitus, coronary artery disease and significant smoking history. All procedures were performed under local anesthesia. Concomitantly or during the same hospitalization two patients underwent adjunctive procedures (coronary artery bypass, lung resection, colon resection).

\section{Results}

Carotid endarterectomies in octogenarian patients represented $18 \%$ of the total carotid endarterectomies performed at AUO "Federico II" of Naples. The postoperative hospital stay averaged 5.4 days for CEA

\footnotetext{
* Correspondence: savanelliantonio@libero.it

Dipartimento Assistenziale di Chirurgia Generale, Geriatrica ed Endoscopia Diagnostica ed Operativa. Università degli Studi di Napoli "Federico II", Napoli, Italy
}

and 3.7 for CAS. Thirty-day morbidity and mortality included $6(16.6 \%)$ death for CEA and $2(4.1 \%)$ death for CAS. There were no postoperative strokes in the CEA group while there were four postoperative strokes in the CAS group. There were 6 cases $(12.5 \%)$ of total complication in the CAS group and 4 cases $(11.1 \%)$ in the CEA group. Long term follow-up results were available. at 3 years survival $30(62 \%)$ in CAS group and 30 (79\%) in CEA group.

\section{Conclusions}

The incidence of stroke, death or procedural myocardial infarction was $12.5 \%$ in the stenting group compared with $(11.1 \%)$ in the endarterectomy group. (CAS n 6 / CEA $\left.n^{\circ} 4\right)$. Risks of any stroke and all-cause of death were higher in stenting group than in the endarterectomy group. There were also fewer haematomas of any severity in the stenting group than in the endarterectomy group.Long-term follow-up is needed to establish the efficacy of carotid artery stenting compared with endarterectomy. In meantime, carotid endarterectomy should remain the treatment of choice for patients suitable for surgery. This experience suggests that carotid endarterectomy can be performed in elderly population with morbidity and mortality rates similar to those in a younger cohort. This suggests that if guidelines similar to those used in younger population are followed, paying close attention to associated risk factors, carotid endarterectomy can be performed safely in the elderly population. With the current trend toward growth of the aging population in our society, this information may become increasingly important for prevention of stroke and preservation of quality of life in a major segment of the population.

Published: 24 August 2011 


\section{References}

1. Treiman RL, Wagner WH, Foran RF, et al: Carotid endarterectomy in the elderly. Ann Vasc Surg 1992, 6:321-324.

2. Pinkerton JA, Gholkar VR: Should patient age be a consideration in carotid endarterectomy? J Vasc Surg 1990, 11:650-658.

3. Rosenthal D, Rudderman RH, Jones DH, et al: Carotid endarterectomy in the octogenarian: Is it appropriate? J Vasc Surg 1986, 3:782-7.

4. Barnett HJ, Taylor DW, Eliasziw M, et al: Benefit of carotid endarterectomy in patients with symptomatic moderate or severe stenosis. North American Symptomatic Carotid endarterectomy Trial Collaborators. N Engl J Med 1998, 339:1415-25.

5. CAVATAS investigators: Endovascular versus surgical treatment in patients with carotid stenosis in the Carotid and Vertebral Artery Transluminal Angioplasty Study (CAVATAS): a randomised trial. Lancet 2001, 357:1729-37.

6. Mas JL, Chatellier G, Beyssen B, et al: Endarterectomy versus stenting in patients with symptomatic severe carotid stenosis. N Engl J Med 2006, 355:1660-71.

doi:10.1186/1471-2318-11-S1-A55

Cite this article as: Savanelli et al:: Carotid endarterectomy versus stenting in octogenarians. BMC Geriatrics 2011 11(Suppl 1):A55.

\section{Submit your next manuscript to BioMed Central} and take full advantage of:

- Convenient online submission

- Thorough peer review

- No space constraints or color figure charges

- Immediate publication on acceptance

- Inclusion in PubMed, CAS, Scopus and Google Scholar

- Research which is freely available for redistribution

Submit your manuscript at www.biomedcentral.com/submit 